\title{
Emergence of Zoonotic Myiasis in Vom and Bukuru Metropolis, Jos South LGA, Plateau State, Nigeria
}

\author{
T.I. Ojemudia, A.O. Olabode, O.I. Okeke, C.O.O.Chukwu, B. N. Duru \\ O. N. Adeyanju, R. I. Ashi, A.U. Nedosa \& G.I.A. Dogo \\ Department of Parasitology and Entomology \\ Federal College of Veterinary and Medical Laboratory Technology \\ Parasitology Division, National Veterinary Research Institute, Vom, Plateau State \\ $\&$ \\ Department of mecine, Nnamdi Azikiwe University, Awka Anabra state, Nigeria \\ E-mail: idamudi2003@yahoo.com
}

Received: August 9, $2010 \quad$ Accepted: August 20, 2010 doi:10.5539/gjhs.v3n1p104

\begin{abstract}
A study was carried out to establish the emergence of cutanous myiasis with its zoonotic implication in Vom and Bukuru metropolis of Jos South Local Government Area of Plateau State. 6 individuals (3 males and 3 females) who were suspected to have boils on their skin were diagnosed to be $100 \%$ infested with the larvae of Cordylobia anthropophaga. Similarly, in an investigation of dogs, out of 510 dogs examined in Evangelical Church of West Africa and NVRI Veterinary clinics, 47(9.2\%) dogs had larvae in their cutanous tissues. Of 300 dogs from ECWA vet clinic 31 (10.3\%) were positive, while $16(7.6 \%)$ were positive from 210 dogs screened in NVRI vet clinic. All results were statistically significant at $\mathrm{P}<0.05$. In comparism, the larvae extracted from human and dogs were all identified to be of Cordylobia anthropophaga. Of 184 Alsatian 13(7.1\%) were positive, of 258 Mongrel 27(10.5\%) were positive, 3(21.4\%) among 14 Doberman were positive and of 54 Rottweiler $4(7.4 \%)$ were positive. Out of the 47 positive cases, $31(66.0 \%)$ were female while $16(34 \%)$ were males. Among the female positive cases Mongrel showed a prevalence of 18(58.1\%). Infestation in July showed a high occurrence of 22(46.8\%). Secondary bacterial infection was encountered in two cases of human infestation.
\end{abstract}

Keywords: Emergence, Myiasis, Larvae, Zoonotic, Diptera

\section{Introduction}

Myiasis is the infestation of the organs or tissues of host animals by the larval stages of dipterous flies, usually known as maggots or grubs. The fly larvae feed directly on necrotic or living tissues. The hosts are usually mammals, occasionally birds and less commonly, amphibians or reptiles (Anna, 2001).

Myiasis is often classified according to the anatomical position in, or on the animal that the larvae infest. They may be broadly described as dermal or sub-dermal or cutanous, nasopharyngeal, ocular, intestinal / enteric or uro-genital. When open wounds are involved, the myiasis is known as traumatic and when boil-like, the lesion is termed furuncular. If the path of the larvae beneath the skin can be traced, the myiasis is designated as creeping eruption. A rare form of blood sucking myiasis is described as sanguivorous (Dada et al, 2005).

Myiasis can also be classified according to the biological relationship of causative fly species and the hosts. This classification includes: obligatory, facultative and accidental. In obligatory, the parasites must have a living host to complete their development and are unable to survive in the absence of the host. In contrast, facultative parasites can develop in both living and dead organic tissues. The accidental myiasis causing larvae are rare or by chance agents of myiasis, which may invade an inappropriate host or which may cause myiasis when fly eggs are accidentally ingested (Jelinek et al, 2000).

The commonly known fly responsible for furuncular myiasis both in man and animal in Africa particularly in Sub-Sahara region is the Cordylobia anthropophaga, commonly known as the "African tumbu fly", the "mango-fly", the "skin maggot-fly", the "ver du cayor", or the worms of cayor" (Tamir et al, 2003). In this region of study, it is locally known as "Tsutsan-pata" by the Hausas, "Nyet" or "Bililir" by the Mangus in Plateau, "Ukpokho-egbe or Idu" by the Igueben (Esan) in Edo State, "Ide-Ola" by the Igalas, "Oii ime aru" by the Ibos etc. 
A different species known as $C$. rhodaini (lungfly) also cause furuncular myiasis but they are only found in rain forest of Africa (Anna, 2001).

The adult flies are non-parasitic and as a result are not seen by the infected individuals. They are stunt, compact flies, 6-12mm long. They are dull yellowish to light-brown with two dark-grey and poorly defined dorsal longitudinal stripes on their thorax. It has four abdominal segments, the face and legs are yellow, (fig: 1a). The second and the third stage larvae can only be seen in the infested host tissue (Oldrouyed et al, 1973).

After fertilization, the female fly produces 100-500 banana-shaped eggs, usually depositing them below the surface of shady and sandy soil, and occasionally on clothes that have often been tainted by traces of urine or faeces (Pkea et al 1995). The fly commonly infests humans by laying its eggs on wet clothes left outdoor to dry for more than a day. The eggs hatch while the larvae burrow into the skin when the clothes are worn un-ironed, (Pepper et al, 2008)

The larvae which are 0.5-1.0 mm long are hatched in 1-3 days and can survive up to 15 days while waiting for their human host to penetrate in as little as 25 seconds on contact. The disturbance of the infested soil surface by a susceptible animal host initiate immediate response from the young larvae that wriggle to the surface in order to penetrate the skin of the host (Kettle, 1995). After penetration, the larvae usually have contact with the environment by the posterior spiracle with which it breathes (Mashhood, 2003). A single larva is found in each cavity within which it develops to second and third stages (Parkhouse, 2004). Massive infestation may induce marked swelling and oedema, especially if larvae are in close proximity to each other, (Fig: 1b). Larvae can penetrate deep into tissues and cause considerable damage and even death (Goksu, et al, 2007). Symptoms that include intense itching, sharp piercing pain, inflammatory papule, purities, eosinophilia, discomfort, malaise and secondary bacterial infections at the sites of infestation can be observed. (Millikan et al,1999).

Larvae require 7-15days to mature and then emerge through the breathing pore and drop to the ground, where it pupates. The adult fly emerges 10-20 days later and the circle begins again. Rats and dogs are the most susceptible host, however, man, monkeys, mongoose, squirrels, leopard, boars, antelopes, cats, goats, pigs, rabbits, guinea pigs, and chickens can also be infested (Varani et al, 2007).

\section{Methodology}

Larvae were at different occasions extracted from 6 different patients who had the same symptoms of painful inflammatory papules at various parts of the body. The patients include; a 34 year old man who had the papule on his groin, and his 2 year old daughter who had a swelling like a nodule on her back and chest (plate 3b), a 23 year old girl with nine swollen sites on her lower arm, back and belly (plate 2a), a 13 year old boy with three swellings at his back and two at the upper part of his left arm, a 4lyear old woman with boil-like swelling on her wrist and a year old baby (male) who had pus extruding from large boil on his chest.

Similarly, in an investigations of dogs, a total of 510 dogs [300 from ECWA and 210 from NVRI veterinary clinics in Vom and Bukuru metropolis, Jos South Local Government Area] for routine check-up were examined.

\section{Extraction and examination of larvae}

The same method of extraction was used in both humans and dogs.

The swollen spots were located and covered with paraffin oil, within a minute, the larva brought out its posterior part from host cavity to obtain air. A little pressure was applied to the side of the inflamed site as shown in plate $2 b$ and $2 \mathrm{c}$, the larvae were obtained, labeled and transported to the laboratory for identification. The larvae were macerated in $3 \mathrm{ml}$ of Potassium hydroxide in a hot water bath for 5 minutes. The spiracles were excised, dehydrated with $70 \%$ and absolute alcohol, cleared in xylene, mounted and examined under the10x objective of the microscope.

\section{Results}

The larvae extracted from human and dogs were identified to be of Cordylobia anthropophaga, (plate 1b, 3a and c respectively).

In Table 1, 2(33.3\%) had secondary bacteria infection of Staphilococcus aureus. Single larva was removed from each of 3 patients, 2 larvae were extracted from the 2 year old female from different sites, 8 larvae were extracted from the 13 year old boy and 5 larvae were extracted from the 23 year old lady, Plate $3 a$. On close interaction, it was discovered that all the patients used infested clothes without ironing. In Table 1, 6 human cases were recorded, 3 were male and 3 were female. 3 were below 15 years while 3 were above.

Of 510 dogs examined, $47(9.2 \%$ ) were infected with larvae of $C$. anthropophaga (Table 2). Of 300 dogs examined in ECWA vet clinic, Bukuru, 31(10.3\%) were infested, and from a total of 210 dogs examined in NVRI vet clinic, 
Vom, 16(7.6\%) were infested. Each dog had an average of 5 larvae extracted from their subcutaneous tissues. Table 3 shows a higher occurrence of $21.4 \%$ in Doberman while Alsatian had the least occurrence of $7.1 \%$. In Table 4, the highest occurrence was found in female having 31(66.0\%), while the male had 16 (34\%). Of the infested females, Mongrel had a higher occurrence of 18(66.7\%). In Table 5, the rate of infestation was highest in the month of July, with 22(46.8\%), followed by June with a prevalence of 21(44.7\%). There was no infestation in May, but a low rate in the month of August with an occurrence of $4(8.5 \%)$. The distribution of infestation among the age group in Table 6 shows an occurrence of 30(63.8\%), being higher between the ages of 1 to 12 months old. All results were statistically significant at $\mathrm{P} \leq 0.05$.

\section{Discusion}

This study confirms that Cordylobia anthropophaga is the etiological agent of cutaneous myiasis in both human and dogs in the study area. The result obtained from this research affirms the global epidemiological study of cutanous myiasis as reported by Goksu, (2007), that, animals such as rats, and dogs, are most susceptible hosts. The incidence in human and dogs occurred during the peak of rain which is suggestive of the risk factor for human infestation since the dogs are in close association with their owners at this season. The smell of these animals and their houses contaminated with urine and feaces attract the adult dipteral fly to human dwellings, hence dog owners may be more at risk of infestation particularly when the hygiene condition is lax. The $100 \%$ infestation in human case in Table 1 shows the susceptibility of human to this parasites.

The use of clothes harboring the life larvae without ironing after wash as confirmed by the patients is a factor for human infestation. The infestation in dogs has a higher prevalence in the month of June and July as shown in Table 5 , this is when the frequency of rainfall is high, the bushes are well grown in the tropics, the animals are forced by rain to stay more in their habitat, the breeding of flies is high and are also driven to human dwelling places. There is no predilection site for infestation, larva could be found in any soft area that it has contact with.

The numbers of larvae found in a host depend on the number of eggs laid on the clothes; hence, there is no multiplication of larva in a host. The only complication in one of the human cases involved surgical removal of the larva and the patient was placed on antibiotics. Complications are partly site and rate of infestation dependent as reported by Adisa, (2004)

The female dogs particularly the Mongrel specie were more susceptible and the preference among them were the younger ones between the age group of 1 to 12 months, (Table 3). The frequent contact with the contaminated sandy soil by dogs enhanced their infestation since contact is required for penetration of intact skin. Due to the attraction of flies to wet clothes with unpleasant odor and sandy soil contaminated by urine or feces, the following recommendation can be observed to control the infestation; (1) there should be prompt removal of the pet's feces, (2) The contaminated site should be flushed with hot water subsequently to kill the larvae. (3) washed clothes should be properly dried, should not be left outdoor for too long, and should be properly ironed before use.(4)The use of insecticide will kill adult flies around human dwellings.(5) Larvae should be removed from hosts and destroyed. Proper management practices should be generally observed while Bio-security measures taken for all domestic animals.

\section{Conclusiion}

This study underscores the need for a detailed travel history and an understanding of the fly's life cycle to prevent its reestablishment in the area and erroneous diagnosis. The nature of the lesions, larval morphological features and spiracular presentation are critical criteria for the diagnosis of this infestation and larva obtained. The consciousness to the seasonal occurrence, avoidance of leaving wet clothes outdoor in the rain, ironing of clothes, and consciousness to personal and environmental hygiene are observable key notes to be free from this infestation and its reemergence.

Researchers should give more attention to myiasis to enhance health and sustainable development in the Tropics. There is need for the Government, NGOs and the privates to combine efforts to combat the emergence of this dipteral flies and its larval infestation in the area to avoid global resurgence.

\section{References}

Adisa C. A., Mbanaso A. (2004). Furuncular myiasis of the breast by the larvae of Tumbu fly. BMC SURGERY, 4:5doi:1471-2482-4-5.

Anna M. West. (2001). Parasitology andpersistence: Infecious Public Health Challenges program in Human Biology, 103. 
Dada-Adegbola H. O., Oluwatogba O. A. (2005). Cutaneous myiasis presenting as Chronic furunculosis. West $A$ FR J Med, 24(4): 346-7.

Goksu T., Lonsdorf A., Jappe U., Junghanss T. (2007). African Tumbu Fly. PUBMED Internist (Berl). 48(3):311-3.

Jelinek T; Nothdurft H; Rieder N; Loescher T. (2000). Cutaneous Myiasis: review of 13cases of travelers returning from tropical countries. Int Dermatol, 39(9): 689-694.

Kpea N; Zywocinski C. (1995). Flies in the flesh": a case report and review of cutaneous myiasis; 55 (1): 47-48.

Mashhood A. A. (2003). Furuncular myiasis by Tumbu fly. J Coll physicians Surg pak. 13(4): 195-7.

Millikan L. (1999). Myiasis. Dermatol, 17: 191-195.

Ockenhouse C., F., Samlaska C. P P., Benson M., Roberts L. W., Eliasson A., Malane S. and Menich M.D. (2007). Department Medicine, Cutaneous Myiasis caused by the Africa tubu fly. Radiology, 218:517-520.

Oldreyed H; and Smith K. G. V. (1973). Insects and other arthropods of medical importance, Chapter 6: pg 289-323.

Otranto D. (2007). Clinical and Esperimental Medicine.A case of furuncular myiasis associated with systemic Imflammation. Parasitol Int., 56(4):330-3.

Parkhouse D. (2004). Cutaneous myiasis due to Tumbu fly during operation Keeling. J R Army Med Corps, 150(1):24-6.

Pepper W. C., BanaragamaSK, Kalsi JS, Karim O. (2008). Cutaneous myiasis of Cordylobia anthropophaga.Urology. PMID: 18436285 [PubMed - as supplied by Publisher]

Richter J, Schmitt M, Müller-Stöver I, Göbels K, Häussinger D. (2008). Sonographic detection of subcutaneous fly larvae in human myiasis. PMID: 17685458 [PubMed - in process]; 36(3):169-73.

Tamir J., Hark J., Schwartz E. (2003). Myiasis with lund's fly in travelers. J Travel Med, 10(5): 293-5.

Varani S., Tassinari D, Elleri D, Forti S, Bernardi F, Lima M, Tursini S, Sambri V. (2007). A case of furuncular myiasis associated with systemic inflammation; 56(4)30-3.

Table 1. Incidence of myiasis in human

\begin{tabular}{|l|l|l|l|l|l|l|}
\hline Sex & NC & NL & PS & IC(\%) & UC(\%) & SBI \\
\hline Male & 3 & 10 & C. anthropophaga & $0(00.0)$ & $3(50.0)$ & $1(16.7 \%)$ \\
\hline Female & 3 & 8 & C. anthropophaga & $0(00.0)$ & $3(50.0)$ & $1(16.7 \%)$ \\
\hline Total & 6 & 18 & & $0(00.0)$ & $6(100.0)$ & $2(33.3 \%)$ \\
\hline
\end{tabular}

NC: number of cases, NL: number of larvae, PS: parasite species, IC: ironed clothe, UC: unironed clothe.SBI: Secondary Bacteria Infection

Table 2. Overall occurrence of parasites in dogs

\begin{tabular}{|l|l|l|l|l|}
\hline Location & no. examined & no. positive & specific \% & overall \% \\
\hline ECWA,Bukuru & 300 & 31 & 10.3 & 6.1 \\
\hline NVRI, vom & 210 & 16 & 7.6 & 3.1 \\
\hline Total & 510 & 47 & 17.9 & 9.2 \\
\hline
\end{tabular}

Table 3. Distribution of parasite in dogs

\begin{tabular}{|l|l|l|l|l|}
\hline Breed & Examined & Positive & $\begin{array}{l}\text { Percentage } \\
\text { specificity }\end{array}$ & Overall \% \\
\hline Alsatian & 184 & 13 & 7.1 & 2.6 \\
\hline Mongrel & 258 & 27 & 10.5 & 5.3 \\
\hline Doberman & 14 & 3 & 21.4 & 0.6 \\
\hline Rottweiler & 54 & 4 & 7.4 & 0.8 \\
\hline Total & 510 & 47 & 46.4 & 9.2 \\
\hline
\end{tabular}


Table 4. Sex distribution

Table 5. Seasonal occurrence

\begin{tabular}{|l|l|l|l|}
\hline Breed & Numbers positive & Females & Males \\
\hline Alsatian & 13 & $8(62.0 \%)$ & $5(38.0 \%)$ \\
\hline Mongrel & 27 & $18(66.7 \%)$ & $9(33.3 \%)$ \\
\hline Doberman & 3 & $2(66.7 \%)$ & $1(33.3 \%)$ \\
\hline Rottweiler & 4 & $3(75.0 \%)$ & $1(25.0 \%)$ \\
\hline Total & 47 & $31(66.0 \%)$ & $16(34.0 \%)$ \\
\hline
\end{tabular}

\begin{tabular}{|l|l|l|l|l|l|}
\hline Breed & May & June & July & August & September \\
\hline Alsatian & 0 & 5 & 7 & 1 & 0 \\
\hline Mongrel & 0 & 13 & 11 & 3 & 0 \\
\hline Doberman & 0 & 1 & 2 & 0 & 0 \\
\hline Rottweiler & 0 & 2 & 2 & 0 & 0 \\
\hline Total & $0(0.0 \%)$ & $21(44.7 \%)$ & $22(46.8 \%)$ & $4(8.5 \%)$ & $0(0.0 \%)$ \\
\hline
\end{tabular}

Table 6. Prevalence rate in age group

\begin{tabular}{|l|l|l|l|}
\hline Breed & $1-12$ months & $2-3$ years & 4years above \\
\hline Alsatian & 9 & 1 & 3 \\
\hline Mongrel & 16 & 7 & 4 \\
\hline Doberman & 2 & 1 & 0 \\
\hline Rottweiler & 3 & 0 & 1 \\
\hline Total & $30(63.8 \%)$ & $9(19.1 \%)$ & $8(17.0 \%)$ \\
\hline
\end{tabular}

(a)

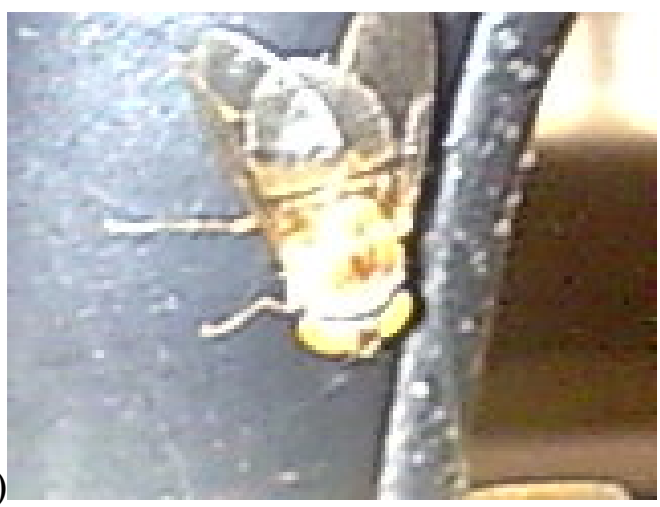

(b)

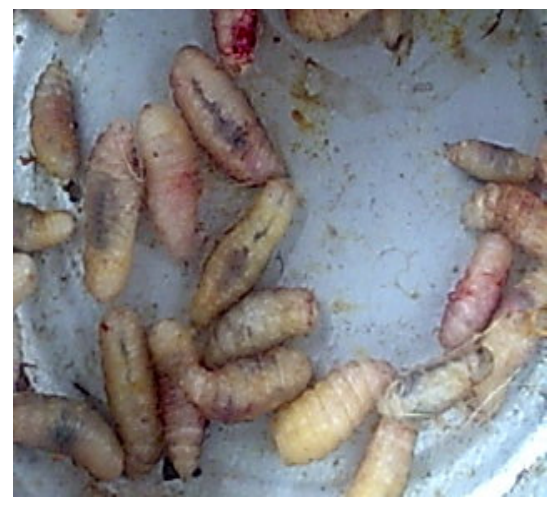

Plate 1. (a) Adult fly of Cordylobia anthropophaga, (b) Larvae of C. anthropophagi from dogs 
(a)

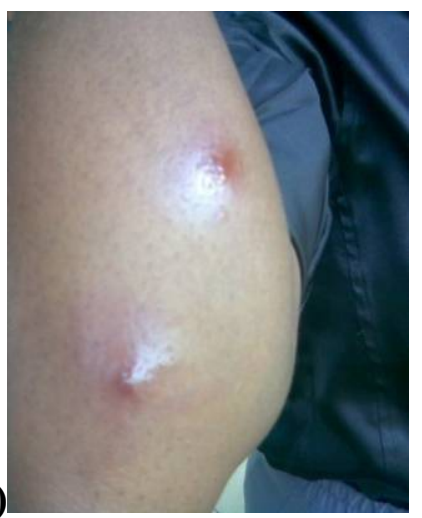

(b)

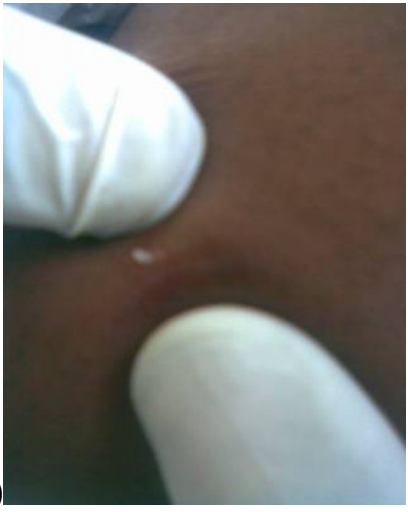

(c)

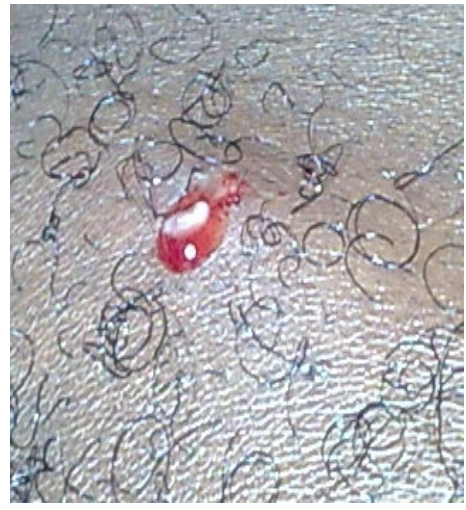

Plate 2. (a) Larva in the cutaneous tissue of the arm. (b) Larva extrusion. (c) Larva from the thigh

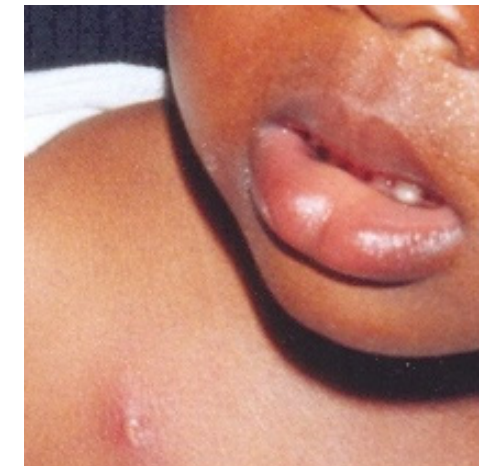

(a)

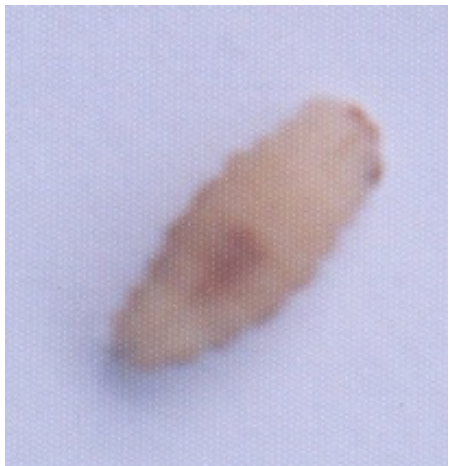

(b)

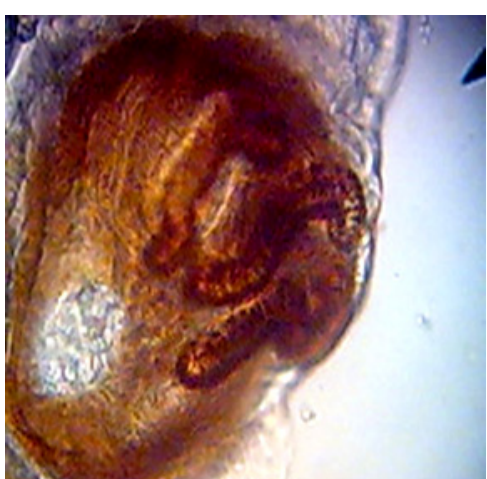

(c)

Plate 3. (a) Papule on the chest of a baby. (b) Larva extruded (c) Spiracular plate of larva 